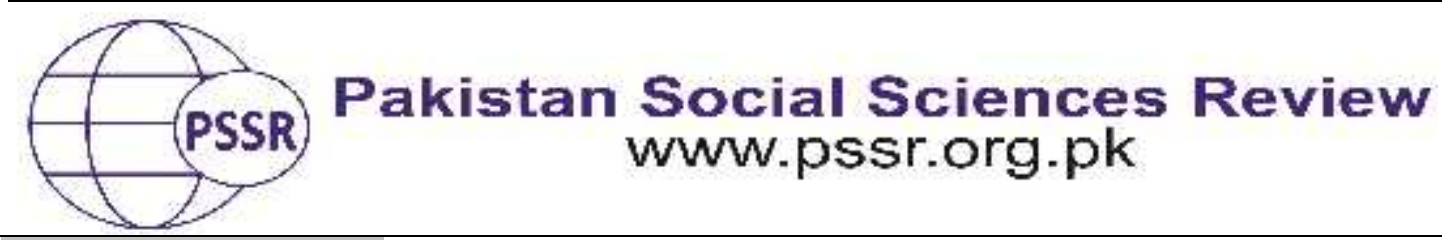

RESEARCH PAPER

\title{
Explicating the Construal of Political Image of Pakistan: A Critical Discourse Analysis of Panama Final Verdict
}

\author{
Zubair Iqbal ${ }^{1}$ Aziz Ullah Khan ${ }^{2}$ Abdul Rafay Khan* 3
}

1. M. Phil Scholar, Applied Linguistics, The University of Lahore, Lahore, Punjab, Pakistan

2. Lecturer, Department of English, University of Science and Technology Bannu, KP, Pakistan

3. Assistant Professor, Department of English, Govt. Islamia College, Civil Lines, Lahore, Punjab, Pakistan

\begin{tabular}{|c|c|}
\hline PAPER INFO & ABSTRACT \\
\hline $\begin{array}{l}\text { Received: } \\
\text { April 12, } 2021 \\
\text { Accepted: } \\
\text { May } 01,2021 \\
\text { Online: } \\
\text { May } 15,2021\end{array}$ & $\begin{array}{l}\text { This study investigates the construal of the political image of } \\
\text { Pakistan in the final verdict of Panama Case with the assumption } \\
\text { that the substantial linguistic choices construing any discourse } \\
\text { provide the way to comprehend the impacts of a specific } \\
\text { discourse. The significance of the study lies in the fact that the }\end{array}$ \\
\hline $\begin{array}{l}\text { Keywords: } \\
\text { Construal, } \\
\text { Critical Discourse } \\
\text { Analysis, } \\
\text { Pakistan, } \\
\text { Panama Case, } \\
\text { Political Image, } \\
\text { Substantial Linguistic } \\
\text { Choices, } \\
\text { Three Dimensional } \\
\text { Model, } \\
\text { Verdict }\end{array}$ & $\begin{array}{l}\text { critical in the political sphere of the country and involve people } \\
\text { of high stature, therefore, it is worth exploring that how the } \\
\text { verdict reflects the political conditions of Pakistan. The data } \\
\text { comprises extracts from the verdict. The data has been analyzed } \\
\text { using Fairclough's three dimensional model of Critical Discourse } \\
\text { Analysis, to highlight that how discursive strategies have been } \\
\text { employed in the verdict to construe and project the political } \\
\text { image of Pakistan. The findings of the study demonstrate that } \\
\text { linguistic choices made by the judges are portraying the Ex- }\end{array}$ \\
\hline $\begin{array}{l}\text { *Corresponding } \\
\text { Author } \\
\text { abdurrafay.uos@ } \\
\text { gmail.com }\end{array}$ & $\begin{array}{l}\text { Prime Minister of Pakistan and his family as corrupt and 'not } \\
\text { Sadiq and Ameen', and the construal of a person, who held the } \\
\text { office of Prime Minister for three times, as corrupt and dishonest } \\
\text { man projects the chaotic and unruly political image of Pakistan. }\end{array}$ \\
\hline
\end{tabular}

\section{Introduction}

Critical Discourse Analysis views language as a social construct which is manipulated according to social contexts and needs. It investigates the power relations control, and dominance exercised through language. The language of the law is a sub-genre of professional discourse. It has got terminological and technical vocabulary with a lot of complexities indispensable to language beyond the understanding of laymen. The decade of the 1970s saw a shift of interest of linguists and sociologists towards exploring the relationships between linguistics and law. In 
the beginning, such studies were devoted to proclaim the language of the law as an abstract entity and approaches were traditional in nature regarding the study of language. The language which is appropriate for the field of law was first time studied decade early 70sbut in a limited sense and the practical approach was not targeted (Fillmore, 1973, p. 132). Although, it was a new beginning in the field of law and linguistics but there was severe criticism from all walks and fields of life towards those who were paying attention to this imperative but neglected discipline (Danet, 1980; Edelman, 1977; Gusfield, 1980). On the whole, those studies were discouraged intentionally because the approaches were traditional with an idealized version in the field of law and language. In the domain of law, the severe criticism was on the written part of the language of law. There were a number of legal scholars who studied and identified many important complexities of legal language and one of them David Mallinkof (1964) thoroughly identified the syntactic and morphological features peculiar to legal language which takes it beyond from the understanding of common persons who are not the part of law community.

With the passage of time, the focus of the researchers shifted from written to spoken language of law that how it is manipulated for the appropriate execution of legal functioning and language is used autonomously for the resolution processes (Farinde, 2009). In the West, a few of the studies with scanty amplitude were also surfaced in Africa and Bolivia which shed light on the relationship between language and law. In Pakistan, the present wave of literature renders a few studies having same orientation. These studies are helpful to a great extent if we take them as role models regarding information in the existing body of knowledge in the Pakistani context.

The discourse used in the court proceeding is a sub-genre of the professional discourse and it has achieved a specific distinct form from the conversation of common persons in their daily routines (Santos, 2004). There are a number of factors which are responsible for the peculiarities indispensable to the language of law including the body of evidences. Critical Discourse Analysis which views language as a social construct is a critical approach which studies the way language manifests power, ideology, social control and discrimination among the discourse participants within a given context of courts (Bulcaen, 2000). The courtroom discourse is mainly consisted of speech acts which are distinct from day to day verbal interactions. Due to emphasis on testimony, it deals with the cause and effect relations. This kind of language is different from informal disputing in which both parties are free to talk about for the given context and to elaborate their evidences but here the things are dealt according to general code of conduct peculiar to the domain of law (Conley, 2005).

\section{Panama case in Pakistan}

The Panama Papers are the documents which were leaked from Mossack Fonseca, a Panama-based law firm which, according to its website, offers "comprehensive legal and trust services." The website goes on to say that the firm 
offers "research, advice, and services for the following jurisdictions: Belize, The Netherlands, Costa Rica, United Kingdom, Malta, Hong Kong, Cyprus, British Virgin Islands, Bahamas, Panama, British Anguilla, Seychelles, Samoa, Nevada, and Wyoming (USA)." Some of those jurisdictions have been labeled tax havens including Panama.

Prime Minister Nawaz Sharif is linked to 9 companies connected to his family name. Those involved are: Hassan Nawaz, Hussain Nawan, Maryam Nawaz. Mr. Sharif was not directly involved in the business interactions detailed in the documents but was implicated in the scandal nonetheless. Throughout the Supreme Court hearing, he maintained that he was not involved. Mr. Sharif's case, and that of his children, will now go to Pakistan's National Accountability Bureau for further investigation. Lawyers for the country's opposition told the court that because Maryam Sharif was underage at the time the business was set up under her name, the company would actually be owned by the prime minister.

\section{Literature Review}

\section{Relationship between language and law}

Language is the most power weapon that human possess as it enables them to express their ideas effectively (Provenzano \& Preite, 2017). Linguistics is the scientific study of language as it explores the nature of language by using scientific method, The verbal messages containing conceptualized experiences are used for social interaction. It implies that society influences language and the language also influences society. Keeping in mind the importance of the connection between the language and society, it can be stated that language awareness is important to understand the society. Language awareness also enables us to be in control while involved in speaking (Fairclough, 1995). The studies in the field of linguistics pay greater attention to the pragmatic and cognitive dimensions of language. Anderson (1980) and Carrell (1988) studied he interactive nature of the message and the crucial role played by cognitive processes in the comprehension and interpretation of discourse. The society's impact on the language and interpretation of discourses cannot be neglected (Halliday, 1985). Similarly, the role of language awareness and the role of culture-oriented perception of discourses and realities in shaping the discourses is important (Fairclough, 1995).

That is the reason the role of language is crucial in the discipline of law. The pragmatic functions of legal language are important to be considered while analyzing courtroom discourse (Onadeko, 2001). Legal discourse depends largely on the explicit rules of evidence as these rules control verbal interactions in the courtroom. This enhances the role of critical discourse analysis theory as the theory explains how language projects and construes power and control. It also explicates the inequality and discrimination existing among the participants of courtroom interaction (Blooamart\&Bulcaen, 2000). 
The relationship between law and language has not only been investigated in the field of linguistics but it has been studied in the other disciplines as well. There are three different approaches which evolved in this regard. One of these three approaches keeps language at the central point and states that law provides help for linguistic analysis and assessing theories related to language (Tiersma, 1999, 2005; Solan\& Peter,1993). For some scholars, the law is a central point (Gibbons, 2003). They argue that language is the tool that helps in understating the legal process and the legal system. The proponents of the third approach are of the view that the fields of psychology, anthropology, and sociology are at the central point (Conely\&O'Barr, 2005). They assert that language is used as a vehicle to understand social and psychological processes and cultural traits within the legal system. The current study follows the third approach that focuses on exploring social interactions, psychological processes and cultural traits carried out through the usage of language.

\section{Critical Discourse Analysis}

CDA is the result of the works produced by a group of scholars including Fairclough, Wodak, Gunther Kress, Theo Van Leeuvem and Teun Van Dijk in the early 1990s. CDA finds its roots in various fields and its central concepts can be traced in the domain of anthropology, sociology, philosophy, pragmatics, and applied linguistics.

CDA is a multidisciplinary approach and this is the reason the various proponents of CDA explain it in different ways. There have been several approaches as to what it is all about. According to Van Dijk (1998:1), "Critical Discourse Analysis is a type of discourse analytical research that prominently studies how social power, dominance, and inequality are enacted, regenerated, resisted through discourse in socio-political context". Critical discourse analysis aims to expose and resist social inequality. Discourse contains ideologies which "are logical, though not bombastically, expressed and reproduced in discourse and communication, including non-verbal semiotic messages, such as pictures, photographs and movies"(VanDijk,1995b:17). Ideologies, framed and sustained in various discourses, equally establish and maintain power relations because linguistic forms that mediate them also express and manipulate power. "Power is signaled not only by grammatical forms within a text but also by a person's control of asocial occasion using the genre of a text" (Wodakibid:11).

Van Dijk, (2000) considers critical discourse analysis as a kind of analytical study that aims to investigate abuse of power, dominance, and inequality and it studies how the entities mentioned above are enacted, produced, reproduced and resisted by the discourse in a socio-political context. Wodak (2001) explains that CDA aims to analyze people and the relations of power and dominance packed in discourse. 


\section{Material and Methods}

\section{Theoretical Framework}

The present study adopts Critical Discourse Analysis (henceforth CDA) as its theoretical framework. CDA provides a framework to study the relationship between society and discourse, text and context, power and language (Luk, 1996, 2002;Fairclough, 2006). Critical Discourse Analysis discloses unequal relations existing in discourse. CDA sees the language as a social construct as the speakers of the language do not use it in the laboratory rather in the wider context within a society. It places the social context at the center and studies the textual structures along with the functioning of these structures in a context.

The present study adopted Fairclough's approach to CDA. Fairclough 3-D model is useful in analyzing both linguistic and semiotic aspects of social interactions. According to Fairclough, all languages are parts of social practices and his framework reveals not only the link of social practices with the properties of language "text" but also explores the relationship between language, power, and ideology. So, a text is analyzed in three dimensions i.e. socio-historical, discursive and textual (Fairclough, 2001). These three dimensions are inter-related to each other.

1. Textual analysis of the visual, verbal and written text.

2. It is an illustration of discourse practices including the production and interpretation of the text.

3. It is related to socio-historical conditions and meaning construction. It deals with issues of power and dominance. The model has been in figure 1 .

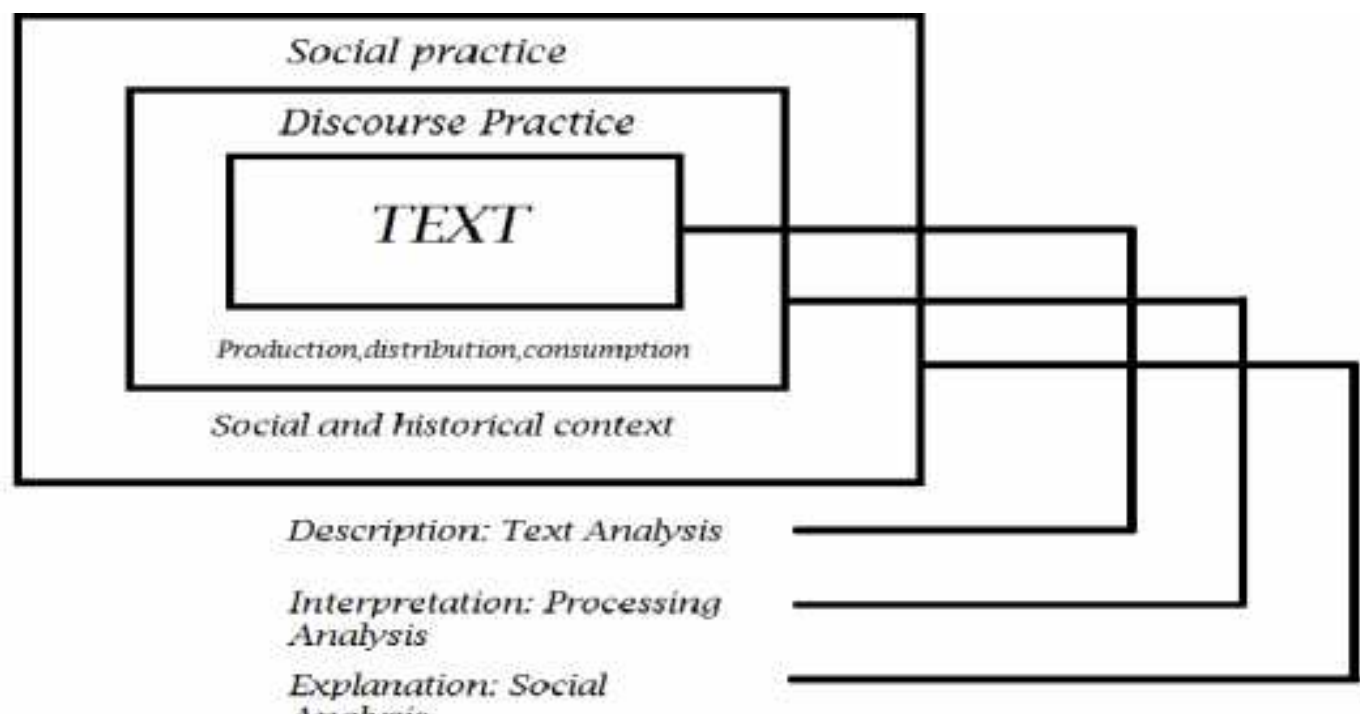

Explanation: Social

Analysis

Figure 3.1 Fairclough's 3D model (2001) 
This approach was taken to analyze the data collected for this study. The linguistic choices made by the judges in the verdict were identified and discussed in the context of the law. The study explicated the manipulation of language to maintain power and hegemonic relations. It was also highlighted that how these linguistic choices were construing the political image of Pakistan.

\section{Research Design}

The purpose of the researcher was to dive deep and unveil the hidden ideologies behind the smooth surface view presented in the Panama Final Verdict by decoding the lexical, grammatical and textual choices made by the judges in the verdict. The main objective of the researcher was to investigate and discover how the power, authority, and hegemony were maintained through these lexico-grammatical choices and how these choices were construing the political image of Pakistan in the outer world. So, mixed-method was found to be the most appropriate methodology for the present study. The descriptive studies are meant to investigate the social pervasive issues in the domain of particular fields in which the researcher gives solutions and recommendations to cope with problems prevailing in the society (Mugenda,2008). Qualitative descriptive method is a method of choice for a researcher who seeks to present the voice of the particular population under study.The quantitative method was useful to be applied in the study to describe the lexico-grammatical choices made by the judges in the verdict in tabular form which included numerical values. So, the mixed-method approach was adopted to meet the objectives of the study.

\section{Population and Sampling}

The population of the study comprises the written discourse of Panama Final Verdict. The data was collected in the form of extracts from the different portions of the Panama Verdict, specifically from the places where judges were commenting on the sanctity of the participants. Twenty sample extracts were selected using the technique of purposive sampling. These extracts constituted the accessible population which is defined as that part of the target population which the researcher can practically reach' (Mugenda, 2008). A purposive sample is based on the characteristics of a population and the objectives of the study.

\section{Instrument of Data Collection}

The instrument of the data collection is the researcher himself who collected data according to the set criterion and objectives by exploring, identifying and selecting the relevant extracts from the Panama Verdict given by the Supreme Court of Pakistan. 


\section{Data Analysis Procedures}

The data were analyzed in an integrated way by using the Fairclough three dimensional model of Critical Discourse Analysis. The data were analyzed in three phases. In the first phase, the data was described according to the first stage of the Fairclough model that is a description of the text. At this stage, the linguistic properties of the text were described and categorized in terms of vocabulary, grammar and textual structures employed in the text by the judges. In the second phase, that is an interpretation, the relation of text with its context was channelized. It was done at two levels, the interpretation of the text as well as the interpretation of the context in which the text was placed. In the last phase, the data was explained concerning power and construal of the political image of Pakistan. The main concern of the explanation is to emphasize the processes of struggle and power relations.

\section{Data Presentation}

The data was presented in both tabular and paragraph forms. In the first attempt, the numerical aspect of data was presented in tables. In the second attempt, those terms have been explained in the paragraphs concerning the socio-political context of Pakistan.

\section{Results and Discussion}

\section{Vocabulary}

The choice of vocabulary shows the ideology of the producers of the texts and determines the social relationship between the participants involved in the text. These paragraphs render the attitude and ideology of judges towards Nawaz Shareef and his immediate family. The ideology of the judges that was made during the course of trials was the negative image of Nawaz Shareef and immediate family. The main theme running through the text as evident through the use of vocabulary is Nawaz Sharif's corruption, money laundering, and other illegal activities. All the words in this extracts e.g.; corruption, corrupt practices, money laundering and dishonest, crime, great fortune, Godfather, guilty are relevant to each other through hyponymy as the Judges have used them with a proper code of language which is typical to the genre of legal language. The text opens with a quotation from a renowned novel having a criminal background. The famous quote from the novel The Godfather has been given in the beginning to foreground the minds of the readers of the verdict about the family of Nawaz Shareef. This classification scheme is the ideological representation of the reality of the case.

\section{Ideologically Contested Words}

The producers of the texts always emphasize their stance with repetitive vocabulary. The verdict of Panama papers by the Supreme Court of Pakistan is also not an exception in this regard in which the judges, the producers of the text, have used different words for many times to make clear their ideology and perception 
regarding Nawaz Shareef and his immediate family. They have deployed the technique of wording and rewording in the text to show that Nawaz Shareef remained involved in the subversive activities of corruption and money laundering while holding the public office.

"Behind every great fortune, there is a crime. Balzac." (s.2)

"Mian Muhammad Nawaz Sharif, the incumbent Prime Minister of Pakistan, and through him his immediate family has amassed huge wealth and assets which have been acquired through means which were illegal and unfair, practices which were unlawful and corrupt and exercise of public authority which was misused and abused." (s.3)

It is evident from these sentences that words like, corruption, corrupt practices, accused and misused, have been used many times throughout the text. The connotation of all these keywords used in the text is negative in evaluation. This repetition of words is deploying an impact of authority and power of the Supreme Court over the participants.

Table1

list of repeated and ideologically loaded words in the extracts

\begin{tabular}{|c|c|c|c|}
\hline Sr. No. & Word(s) & $\begin{array}{c}\text { Word (s) } \\
\text { Derivatives }\end{array}$ & Frequency/Times \\
\hline 1 & Corruption & & 3 \\
\hline 2 & Corrupt Practices & Corruption & 2 \\
\hline 3 & Accused & Accusation & 2 \\
\hline 4 & Misused & Misuse & 3 \\
\hline 5 & Money Laundering & Laundering & 4 \\
\hline 6 & Dishonest & Dishonesty & 2 \\
\hline 7 & Crime & Crimes & 2 \\
\hline 8 & Corrupt & Corruption & 2 \\
\hline 9 & Allegation & Allegation & 3 \\
\hline 10 & Properties & & 13 \\
\hline 11 & Vehemence & Vehemently & 3 \\
\hline 12 & Owned & Ownership & 2 \\
\hline 13 & Satisfaction & & 3 \\
\hline 14 & False/ Untrue & & 3 \\
\hline 15 & Disqualify & $\begin{array}{l}\text { Disqualification/ } \\
\text { Disqualifying }\end{array}$ & 2 \\
\hline 16 & Disqualifying & & 1 \\
\hline 17 & Source of funds & & 4 \\
\hline 18 & Real Estate Business & & 5 \\
\hline 19 & Truth & & 4 \\
\hline 20 & Resources & & 3 \\
\hline 21 & Open Book & & 1 \\
\hline
\end{tabular}




\begin{tabular}{lcc}
\hline 22 & Concealed & 1 \\
\hline 23 & Juxtaposed & 1 \\
\hline 24 & Mutually Destructive & 1 \\
\hline 25 & Coexist simultaneously & 1 \\
\hline 26 & Divergent Explanation & 1 \\
\hline 27 & Statement & 5 \\
\hline 28 & Failed & 3 \\
\hline 29 & Funds & 3 \\
\hline 30 & Execute & 3 \\
\hline 31 & Statement & 1 \\
\hline 32 & Unspecific terms & 1 \\
\hline 33 & Evasive & 1 \\
\hline 34 & Correspondence & 2 \\
\hline 35 & Record & 6 \\
\hline 36 & Properties & 11 \\
\hline 37 & Wealth & 2 \\
\hline 38 & Source & 2 \\
\hline 39 & Owning & 6 \\
\hline 40 & Correspondence & 1 \\
\hline
\end{tabular}

All kinds of texts are written with some specific ideologies. The words are highly political because they are used as a tool to covey a certain message and ideology. A close look at the text of Panama's final verdict reveals that the words have been used with a specific ideology. The purpose of using these words, which are ideologically contested, is to associate an image of a criminal family with the family of Nawaz Shareef.

"In the last two and a half decades there had been a constant murmur nationally as well internationally about respondent No. 1 indulging in corruption, corrupt practices, and money laundering, etc. with the active assistance and involvement of respondent No. 10 and some specified properties in London, the United Kingdom had been identified as having been acquired by respondent No. 1 through ill-gotten or laundered money." (s.4)

The word Mafia is not a general connotative word rather it is always used to show the criminal intent or action of a person or organization. In the Panama Verdict, the word mafia associates the family of Nawaz Shareef with the family of Godfather, who was a criminal family of America. The word Godfather is also not a positive word for any connotation as it also relates to the criminal side of Nawaz Shareef and his immediate family with the American mafia family. The judges have bluntly used this word because they wanted to show the real image of Nawaz Shareef. The next words white color criminals are also ideologically loaded because they are foregrounding the readers' minds about the subversive activities and illegal occupation of state reserves by Nawaz Shareef while holding the public office. The use of this vocabulary shows that judges are completely authoritative and free to use the language in their typical way for a given purpose. 


\section{Euphemistic Expression}

Euphemistic expressions are used to mitigate the overall impact of texts but as far as the Panama paper is concerned, there is less use of euphemistic expressions. It is evident from the lexical choices that the text lacks euphemistic expressions altogether as the judges have a complete authority to use the language. The words like accused, misused, crime and guilty are not the euphemistic expressions but they are creating a sense of directness. The significance of using these direct expressions is to maintain power relations between Nawaz Shareef and his family and the Supreme Court of Pakistan. The producers of the text have manipulated the language to produce hegemonic relations and legitimized the discursive structures of power of the court with Nawaz Shareef. That is the reason behind using direct expressions instead of euphemistic expressions.

Table2

List of Euphemistic Expressions in the Extracts

\begin{tabular}{cc}
\hline Sr. No. & Euphemism/ Directness \\
\hline 1 & Accused \\
\hline 2 & Misused \\
\hline 3 & Guilty \\
\hline 4 & Dishonest \\
\hline 5 & Money Launderer \\
\hline 6 & Substantially untrue \\
\hline 7 & False Statement \\
\hline 8 & Mere press statement \\
\hline 9 & Disqualifying \\
\hline 10 & Destroyed credibility \\
\hline 11 & Asserted \\
\hline 12 & Vehemently argued \\
\hline 13 & Categorically Said \\
\hline 14 & Claimed \\
\hline 15 & Established beyond doubt \\
\hline 16 & Juxtaposed \\
\hline 17 & All was not well \\
\hline 18 & Obvious \\
\hline 19 & Failed \\
\hline 20 & Evasive \\
\hline 21 & Without reference and exactitude \\
\hline 22 & Most Generalized \\
\hline 23 & No trust connected \\
\hline 24 & Seriously damaged \\
\hline 25 & \\
\hline 26 & Unfortunate \\
\hline
\end{tabular}




\section{Formality/Informality Lexical}

Legal texts are formal in language and they become the part of legal genre with the legal code of the constitution. The language of the Panama Final verdict was formal and expressing the theme of corruption of Nawaz Shareef. The words are highly formal accordingly with legal language codes and construing the reality of the Respondent no.1, Nawaz Shareef. The purpose of using formal language in the legal texts is to remain impartial and authoritative while commenting on the legal proceedings and verdicts. In the Panama Papers, the judges are formally commenting on the money laundering and subversive activities of Nawaz Shareef by using formal language. Although, the words are simple and self -explanatory yet they have been used with a formal code of conduct of the law domain.

\section{Grammar}

The experiential values of grammatical features in a text are meant to create a relationship among the participants involved in the text. According to Fairclough, these grammatical features are the determiners of cohesion and coherence in the texts. As far as the Panama papers are concerned, the grammatical features are describing the relationships of Nawaz Shareef and his immediate family with the criminal intents and actions they committed during the powerful aura.

Process and Participants

Tables 3

Processes and participants in the extracts

\begin{tabular}{cccc}
\hline Sr. No. & Participant & Process & Process type \\
\hline 1 & The godfather & recounted & Mental \\
\hline 2 & Author & Selected & Mental \\
\hline 3 & Epigraph & was & relational \\
\hline 4 & There & Is & Existential \\
\hline 5 & It & Is & Relational \\
\hline 6 & The present case & Revolves & Relational \\
\hline 7 & Very sentence & Attributed & Mental \\
\hline 8 & It & alleged & Relational \\
\hline 9 & Imran khan & Holding & Behavioral \\
\hline 10 & Family & Amassed & Material \\
\hline 11 & assets & Acquired & Material \\
\hline 12 & wealth & acquired & Material \\
\hline 13 & practices & were & Relational \\
\hline 14 & public authority & misused & Material \\
\hline 15 & there & Had been & Relational \\
\hline 16 & United kingdom & identified & Mental \\
\hline 17 & Respondent no.1 & Acquired & Material \\
\hline 18 & Respondent no.1 & Is & Relational \\
\hline
\end{tabular}




\begin{tabular}{cccc}
\hline 19 & Article (62) & Required & Relational \\
\hline 20 & $\mathrm{He}$ & failed & Material \\
\hline 21 & $\mathrm{He}$ & Advanced & Material \\
\hline 22 & National assembly & Had been & Relational \\
\hline 23 & $\mathrm{He}$ & disqualified & Material \\
\hline 24 & $\mathrm{He}$ & Being & Relational \\
\hline
\end{tabular}

The close analysis of the processes and participants revealed that all types of sentences have been used in the text. The upper table contains the list of processes and participants which are included, mental, relational, existential and material. The first two sentences are active in structure and agencies are clear. The third sentence contains a passive clause but the agency is clear in the clause. The fourth sentence is also active and the agency is clear. The fifth sentence is active as well and contains a clear indication of the agency. The presence of agency in all of the five sentences shows that the judges do not have any kind of ambiguity in the mind while stating the verdict against Nawaz Shareef and his family. Agency is kept clear when the writer wants to give a clear understanding of the participants of a sentence. The first line of the verdict shows that The Godfather is referring to Nawaz Shareef and the rest of the introduction contains the information about Imran Khan.

All of the sentences in the text are positive excluding the fifth sentence. A close look at the table of modes that have been used in the text shows that the majority of sentences are declarative. The first four sentences are declarative while only the last sentence is a grammatical question. The purpose of keeping the declarative mood is to show the straightforward nature of the text. The judges directly commented on the condition of Nawaz Shareef and his immediate family by declaring the facts and figures which came across during the court trials of the case.

\section{Modes}

Table4

Modes in the extracts

\begin{tabular}{|c|c|c|}
\hline Sr. No. & Declarative & Grammatical Question \\
\hline 1 & Sentence No.1 & \\
\hline 2 & Sentence No.2 & \\
\hline 3 & Sentence No.3 & \\
\hline 4 & Sentence No.4 & \\
\hline 5 & Sentence No.5 & \\
\hline 6 & Sentence No.6 & \\
\hline 7 & Sentence No.7 & \\
\hline 8 & Sentence No.8 & \\
\hline 9 & Sentence No.9 & \\
\hline 10 & Sentence No.10 & \\
\hline 11 & Sentence No.11 & \\
\hline 12 & Sentence No.12 & \\
\hline
\end{tabular}




\begin{tabular}{ll}
\hline 13 & Sentence No.13 \\
\hline 14 & Sentence No.14 \\
\hline 15 & Sentence No.15 \\
\hline 16 & Sentence No.16 \\
\hline 17 & Sentence No.17 \\
\hline
\end{tabular}

\section{Relational/Expressive Modality in the text}

According to Fairclough (2001), the modality is known as the realization of authority using modal auxiliaries, modal adverbs or tenses. There are two types of modality which depend on the direction of authority and power. The first one is called relational modality which shows the authority of different participants while the second type is called expressive modality which shows the writer's or speaker's evaluation of truth. In the Panama paper, the judges have complete authority and that is why they have used the modal auxiliaries verbs like must, should etc. There is expressive modality in the text as the producer of the text is evaluating the 'truth'. In the first three sentences, the producer of the text related to the family of Nawaz Shareef with the family of Godfather and foregrounded the minds of the readers. While in the rest of the sentences, the writer expressed the truth about the family of Nawaz Shareef by giving facts and figures.

\section{Coordination and Subordination}

The first sentence contains two clauses and both of the clauses are independent. The clauses have been joined together with the use of coordinate conjunction And. The second sentence contains only a single clause. The third sentence consists of nine clauses. The first clause is independent while the remaining eight clauses are dependent. The dependency status has been maintained through the use of subordinate conjunction including That, As, And, and Which. The fourth sentence contains two independent clauses that have been joined together by the use of coordinate conjunction And. The connectors including whether, as, and, or, have been used as cohesive devices in the fifth sentence. The purpose of using this mixture of independent and dependent clauses is to establish a logical connectivity between the facts and figures which came to light during the trials of Panama Verdict.

\section{Textual Structures}

The present paragraph is the written verdict of the legal domain which is a monologue in nature. There is no turn-taking in the text because the writer has used declarative mode in asserting the court's perception of the Panama case. The genre of the text is 'written expression of verdict 'which are meant to be declared publically. The extracts under analysis have been taken from the introductory section of the written document. 


\section{Interpretation and Explanation}

The lexical, grammatical and textual features of the text that have been chosen out of available choices by the writers reflect conscious ideological construction.

The lexical choices made in the text represent the typical characteristics of the language of the law. The classification schemes used in the text are aimed to formulate the intended ideological sense in the minds of readers. The writer begins with the use of the technique of allusion to make a connection between the criminal and mafia portrayed in the novel "The Godfather" by Mario Puzo and Respondent No.1, Nawaz Shareef. The writer, through this reference, has tried to explain that the family of respondent no.1 has been involved in corruption and misuse of power just like the family of the criminals and mafia in the novel. There are many words which are construing the negative image of the family under trial. The use of words like corruption, corrupt practices, misused, guilty and abused are significantly potential choices in constructing a distorted image of respondent no.1. It is worthy to note that the lexical choices are linked to each other by the use of hyponymy as all of the words are linked to corruption. The analysis of the vocabulary reflects that no euphemistic expressions have been used as the legal system demand clarity of expressions. The legal system also demands that the language must be used in a highly formal way, and the analysis shows that the text has been written in highly formal language. The metaphor has been used to make a connection between the corrupt respondent no.1, who is the Prime Minister of Pakistan, and the powerful and corrupt criminal character represented in The Godfather.

Along with the lexical choices, the grammatical features of the text are also crucial in ideological construal. The language used in the verdicts reflects the excessive use of event processes as the focus remains on the events. The event processes, as these are about the events, make the agency unimportant or unclear. The use of passive voice is also evident in the text and it is also making the agency unclear. The agency has been made unclear advertently as law pursuit focuses on the event or the action rather than the agency. The text is written in a declarative mood which shows that the judges are directly commenting on the corruption of Nawaz Shareef and his immediate family. In the case of this text, expressive modality is present as the judges are evaluating the truth. The role of judges is to remain neutral and objective. That is the reason the text lacks the use of first and second-person pronouns. The text is cohesive and coherent and these properties have been built in the text through the use of coordination, subordination, endophoric references, and exophoric references which are evident in the text. These techniques have been used to establish cohesion and coherence in the text.

The textual structure of the verdict shows that it is a monologue. The verdict is given by the judges after evaluating the case in detail. As the extract under analysis has been taken from the introductory part of the verdict, it covers the overall overview of the case and the remarks of the judge on the case. 


\section{Conclusion}

Technical vocabulary is political in nature as it shapes the reality of things within given contexts. The study has meticulously answered the posed question. It has rendered the power symmetry and power aura of the Supreme Court of Pakistan. The analysis of the data, carried out to explore the construal of political image of Pakistan in Panama Verdict, renders the result that the lexico-grammatical choices made in the verdict reflect power and authority lies with the Supreme Court of Pakistan and that even a person of high stature like Nawaz Shareef is equal to an ordinary man in the court of law. The linguistic analysis has been done at different level. At the first level (Description), ten questions of Fairclough's three dimensional model were applied. In these questions, vocabulary, grammar and the textual structure were discussed. These comprised repeated vocabulary, ideologically loaded content, moods, modality etc. At the second level, the collected data were interpreted in the Pakistani context that how these words could be meaningful under the purview of Critical Discourse Analysis. The last level was the explanation of described vocabulary in the context of Panama verdict. In the Panama verdict, language has been manipulated by making certain choices, repetition of ideologically contested vocabulary, grammatical expressions and textual structure of the text. The Panama verdict declared by the Supreme Court of Pakistan affirmed Mian Nawaz Shareef, Maryam Nawaz, Captain Safdar, and Ishaq Dar as offenders. The judges wrote about Nawaz Shareef and immediate family in the major portion of the verdict and they comparatively focused more on his subversive activities. The judges declare his family as an accomplice in his criminal activities. For instance, the judge ridicules at a moment when he describes that the children of Nawaz Shareef remembered and reproduced the details of the property that was purchased when they were minors or at best toddlers while their father forgot everything about this property. 


\section{References}

Andersdon, J. R. (1980). Cognitive Psychology and Its Implications. San Francisco: Freeman.

Blommaert, J., \&Bulcaen, C. (2000). Critical Discourse Analysis. Annual Review of Anthropology, 29(1), 447-466. doi:10.1146/annurev.anthro.29.1.447

Carrell, P. L., Eisterhold J. C. (1988). Interactive Approaches to Second Language Learning. Cambridge : Cambridge University press .

Chouliaraki, L., \& Fairclough, N. (1999). Discourse in Late Modernity: Rethinking critical discourse analysis. UK Edinburgh: Edinburgh University Press.

Conley, J. M. (2005). Just words: Law, language and power (2 ed.). Chicago : Cambridge University Press.

Danet, B. (1980). Language in the legal process . Law and Society Review , 14 (3), 446564.

Dijk, T. A. (1991). Racism and the Press . London \& New York: Routledge.

Dijk, T. A. (1992). Discourse and the denial of racism. Discourse and Society, 87-118.

Dijk, T. V. (1993). Elite Discourse and Rascism. London: Sage Publications.

Dijk, T. V. (1995). Aims of Critical Discourse Analysis. Japanese Discourse, 1, 17-27.

Ehrlich, S. (2001). Representing Rape: Language and Sexual Consent. Psychology Press.

Fairclough, N. (1989). Language and power. London: Longman.

Fairclough, N. (1995). Language and power. London: Longman.

Farinde, O. R. (2009). Forensic linguistics: An introduction to the study of linguistics. Lincom Europa : Muenchen .

Fillmore, C. (1973). A grammarian looks to sociolinguistics. In Roger W. Shuy (Ed.) Sociolinguistics: Current trends and prospects. Washington, DC: Georgetown University Press.

Halliday, M. (1985). An Introduction to Functional Grammar, Arnold. Linguistics: Recent Theory and Practice. London: Pinter.

Luke, A. (2002). 'Beyond Science and Ideology Critique: Developments in Critical Discourse Analysis'. Annual Review of Applied Linguistics. USA: Cambridge University Press. 
Mellinkoff, D. (1963). The language of the law. Boston: Little Brown.

Mugenda, A. (2008). Social science research: Theory and principles. Nairobi: Applied Research and Training Services.

O'Barr, W. M. (1982). Linguistic evidence: Language power and strategy in the courtroom. New York: Academic Press.

Ogorek, R. (2004). 'Ichkenne das Reglementnicht, habeesaberimmerbefolgt!' MetatheoretischeAnmerkungenzurVerständnisdebatte. In K.D. Lerch (ed.) RechtVerstehen. Verständlichkeit, Missverständlichkeit und Unverständlichkeit von Recht (pp. 297-305. Berlin/New York: de Gruyter

Santos, M. (2004). A pragmalinguistic analysis of courtroom questions in a multilingual context. Philippines: De La Salle University Press.

Solan, Lawrence (1993). The Language of Judges. Chicago: University of Chicago Press.

Tiersma, P. (1999). Legal Language. Chicago: University of Chicago Press. 